\title{
Research on Innovation and Development of Enterprise Salary Performance Management in the Era of Large Data
}

\author{
Jian Li \\ Qilu Normal University China Shandong 250013
}

Keywords: Large data; Salary performance management; Innovation; Development

\begin{abstract}
In the era of big data, the innovation of enterprise salary performance management is directly related to the level of human resource management, and it is one of the prerequisites for ensuring the competitiveness of enterprises. This paper analyzes the positive impact of big data on the innovation of enterprise salary performance management, and analyzes the current development of compensation performance management combined with specific situations, and puts forward some suggestions on how to effectively promote the innovation and development of compensation performance management.

With the development of information technology and the popularity of the network, the content richness and complexity of information has increased in magnitude than in the past. This makes the traditional mode of data collection and processing in artificial form being no longer used, and big data has become a new mode favored by many managers. As an important part of human resource management, the innovation and development of enterprises directly determine the ability of enterprises in human resource management, and is considered to be one of the core elements that decide the competitiveness of enterprises. Therefore, how to make use of big data to innovate the salary performance management mode and realize the improvement and comprehensive development of enterprise benefits has become a new topic for human resource managers.
\end{abstract}

\section{Part One the Effect of Large Data on the Innovation of Enterprise Salary Performance Management}

\section{Improving the Efficiency and Quality of Enterprise Salary Performance Management}

For the enterprise salary performance data, it includes basic data of staff, capacity data, efficiency data and the potential data, of which the efficiency data directly reflects the staff work efficiency, product failure rate and so on, is mainly considered indicators for performance appraisal. At the same time, the capacity data and potential data were overall ability for employees (such as educational background and work experience) and expected growth potential, so that if it is able to effectively use big data to deal with these data, you can directly view combined with structured data and semi-structured data, efficiently and quickly help managers consider employees in all aspects of quality according to the actual needs of the job, and to provide competitive salary.

\section{Strengthening the Core Competitiveness of Enterprises}

For enterprises, the use of large data to strengthen the level of human resources management has become the best choice under the trend of the knowledge capital to the operating cost. On the one hand, enterprises have relatively perfect salary management system to attract and retain talents, thus taking the initiative in the fierce competition in the market; on the other hand, through the improvement of the salary management system can realize the intrinsic motivation of employees, in order to ensure that enterprises in the face of increasingly stringent customer requirements and more rapid products the life cycle and technological innovation more efficient while still occupy the dominant position in the industry. Innovation of salary performance management implementation in the context of large data can simplify the performance management process, strengthen the enterprise human resources management capabilities, and strengthen the ability of cross regional business management, provided the prerequisite for the enterprise internationalization operation. At the same time, innovation of performance management for the enterprise also can help the enterprise culture a group of skilled use of large data management personnel, improve the enterprise ability to use big data. That is to say, the innovation of salary performance management can 
improve the level of human resource management and improve the core competitiveness of enterprises.

Fully Understanding the Employees' Potential Ability and Improving the Enthusiasm of the Employees

Through the comprehensive consideration of all aspects of the data on the staff of the personnel of the enterprise performance management, employee performance can determine its future potential, such as turnover, job promotion, promotion of space frequency and so on, thus the demand for staff to conduct a comprehensive understanding to mobilize the enthusiasm of staff. At the same time, according to the performance evaluation system for mining potential ability of employees can guarantee the improvement of work efficiency, so as to promote the production and operation of enterprises.

Realizing Good Talent Planning Within the Enterprise

One of the key tasks of the enterprise performance management is to ensure internal talent to realize the enterprise value, and to mobilize the initiative work exploring the implementation of its potential. Through the use of big data, enterprises can carry out targeted training of personnel, so that talents can strengthen certain aspects of professional skills with the realization of personal value, and create more outstanding performance to receive the corresponding performance return in salary. Therefore, the innovation of enterprise salary performance management is the effective guarantee for the enterprise itself to survive and develop in the fierce market competition.

\section{Part Two Common Problems in the Development of Enterprise Salary Performance Management in the Era of Large Data}

\section{Some Managers can't Adapt to the New Management Model}

Large data in the current mass with the improvement of cognition has been widely used, and gradually develop the information storage hardware technology and high-speed progress largely overcoming a few years ago on the use of large data in terms of some limitations and inconvenience, this makes a lot of enterprises have already begun the actual application in the management of the implementation of data. However, because the sensitivity is not high, some managers lack of entrepreneurial spirit who will still be considered priority use of outdated management mode and management idea, and the specific work of performance management under the era of large data lack of knowledge. In addition, realizing the innovation of enterprise performance management requires managers to master the comprehensive skills, data mining classified data from large data, and the part of human resources management staff in this area is also slightly less the innovation and development process of the enterprise's salary performance that is hindered by the lack of it.

\section{The Existing Compensation System has Restricted the Innovation of Salary Performance Management}

Due to the transitional period of enterprise reform, some traditional enterprises will have a certain degree of brain drain when adopting innovation mode on salary performance management innovation. On the one hand, the application of large data in the salary performance assessment will lead to the intensification of talent competition. The reason is that the performance management can improve the ability to develop the chain effect, which enhances the enterprise's human resources management, and it will play an active role in staff recruitment, staff training and other aspects attracting more talents, but due to limited jobs, which will intensify internal competition among talents, and it will inevitably appear the phenomenon of brain drain. On the other hand, in the enterprise, innovation policy in the exploration of some talents salary performance appraisal there may be some deviation stage making it easier to produce psychological gap and resulting in loss of talent. 


\section{Part Three the Concrete Methods of Innovation and Development of Enterprise Salary Performance Management}

\section{Making Clear the Specific Direction of Compensation Performance Management Innovation Based on Enterprise Reality}

Enterprises should combine the actual situation of enterprises, taking into account the direction of development of enterprises and the policy trend of the industry, and make clear the direction of their performance management innovation. The primary task is to strengthen the enterprise management personnel's understanding of large data, and through the study of the industry's best case experience on effective management of large data fusion method for internal use and enterprise management innovation. At the same time, taking the specialized and personalized solutions, such as the need to introduce innovative talents of the enterprises can encourage talent retention and improving their work enthusiasm through increased technological innovation performance management in proportion. And for some popular areas of the small company, you can use large data tools, basic data, ability to improve staff performance appraisal data increasing the proportion of wage increases to attract young high level candidates, guarantee the innovation of salary enterprise performance management that can bring more possibilities for the survival and development of enterprises.

\section{Strengthening the Comprehensive Quality of Salary Performance Managers}

For the managers of salary performance, we should cultivate their comprehensive quality from two angles of awareness raising and skill training. First of all, to improve the performance management personnel to use big data to carry out related work consciousness, make them recognize the limitations of the traditional methods under the age of big data, there are specific methods and further cognitive application of large data tools to realize the modern method and the traditional method of convergence; secondly, to strengthen the application of large data of human skill training resource management personnel, so that managers can effectively rely on high quality data and quickly complete the employee salary management and performance appraisal work.

\section{Adopting a More Comprehensive Performance Evaluation Model}

Firstly, the application of large data should be more scientific. Evaluation index of employees should provide structured data and unstructured data tools in large data analysis or inductive list by quantitative form sorted out, and can use some technical methods for screening to improve work efficiency and reduce the subjectivity of performance appraisal. As for some middle position performance appraisal, it can be composed of senior positions according to the expected results with the future value of the company and the personnel turnover rate level to set a quantitative reference line, and management personnel can be directly related to the reference standard for rapid evaluation of the specific performance of the employees in the examination, and make adjustments to the salary.

Secondly, the subjectivity and contingency of performance assessment should be reduced. A feasible plan is to increase the number of performance appraisers, that is the "360 degree performance appraisal", through the use of big data tools to integrate the opinions of employees, colleagues, department heads and quartet evaluators so as to improve the fairness of evaluation results.

Again, it should adopt the principle of clear performance appraisal, which clearly points out the position and staff positions should have the knowledge, ability and quality and other requirements, and the enterprise should play on the staff of the utility, or expect behavior that allow employees to pay for performance management executive mode with a comprehensive understanding, so as to promote the innovation and development of enterprise salary performance management.

\section{Conclusion}

The innovation and development of enterprise salary performance management is one of the key factors to improve the core competitiveness of enterprises. For enterprise managers, it must be aware of the current era of large data upgrade brings opportunities to the management work, attitude and sense of innovation, and formulated according to the compensation performance innovation 
management method suitable to its own reality, to improve the overall quality of management and optimize the performance appraisal model in order to achieve security objectives approach to innovation pay for performance management, laying the foundation for the long-term development of enterprises.

\section{Reference}

[1] Hui Yang. Probe into the way of the salary performance management of the state-owned enterprises under the new situation[J].Market Modernization,2016,(26):68-69.

[2] Cheng Zhao. A brief discussion on enterprise performance management and salary management from the perspective of innovative ideas[J].Enterprise Reform and Management,2016,(04):81.

[3] Suzhen Zhang. Exploring the innovation strategy of enterprise salary management and performance management[J].Economist,2014,(12):133-134. 